
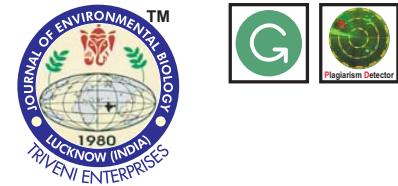

\title{
Seasonal variations of rotifers from the high altitude Llano reservoir (State of Mexico, Mexico)
}

\section{Authors Info \\ M.E. Muñoz-Colmenares', S.S.S. Sarma ${ }^{2 *}$ and S. Nandini ${ }^{2}$ \\ ${ }^{1}$ PCMyL, National Autonomous University of Mexico, Circuito Exterior S/N, Ciudad Universitaria, Delegación Coyoacán, Mexico City 04510,Mexico \\ 'Laboratory of Aquatic Zoology, National Autonomous University of Mexico, Campus Iztacala, Av. de Los Barrios No.1, AP 314, 54090, Los Reyes, Tlalnepantla, State of Mexico, Mexico}

${ }^{*}$ Corresponding Author Email : ssssarma@gmail.com

Key words

CCA analysis

Llano reservoir

Species diversity

Seasonal variations

Publication Info

Paper received: 16.05 .2016

Revised received : 07.12.2016

Re-revised received: 18.01 .2017

Accepted : 24.02 .2017

\section{Abstract}

Aim: Llano reservoir is a high altitude waterbody and is of recreational importance in Mexico. It is also a source of revenue through fisheries. Though the reservoir was constructed nearly 6 decades ago, quantitative information on the zooplankton abundance is not available. The aim of the present study was to present data on the seasonal variations of rotifers from the high altitude waterbody Llano dam (State of Mexico) during a one year period.

Methodology: Rotifer sampling was done monthly from 5 different littoral zones for one year (August 2014 to July 2015). Eighty liters of superficial water from the reservoir were concentrated to $200 \mathrm{ml}$ through a plankton net of $50 \mu \mathrm{m}$ pore size and fixed in $4 \%$ formalin. Selected physico-chemical parameters (dissolved oxygen, temperature, $\mathrm{pH}$, conductivity and nutrients $\left(\mathrm{NO}_{3}\right.$ and $\left.\mathrm{PO}_{4}^{-3}\right)$ and Chlorophyll a were also measured.

Results: Temperature varied from $10-20^{\circ} \mathrm{C}$ and $\mathrm{pH}$ 5-8. The reservoir had low turbidity $(<3 \mathrm{NTU})$, nitrates $\left(<60 \mu \mathrm{g} \mathrm{L}^{-1}\right)$, phosphates $\left(<5 \mu \mathrm{g} \mathrm{L}^{-1}\right)$ and chlorophyll a $\left(6-8 \mu \mathrm{L} \mathrm{L}^{-1}\right)$. In all, 84 species of monogonont rotifers (from 18 families and 39 genera) and 13 cladoceran species (from 3 families) were recorded. Aspelta angusta, Eosphora thoa, Trichocerca insulana and Lepadella punctata are new records for Mexico. Polyarthra vulgaris had the highest frequency of occurrence $(98 \%)$, followed by Trichocerca bidens (90\%) and Trichotria tectractis (75\%). During April, we recorded the highest density (825 ind. $\left.~^{-1}\right)$ of all rotifer species together, meanwhile for the rest of months, the density was low $<300$ ind. $\mathrm{I}^{-1}$. Shannon-Wiener index varied from 1.0 to 4.2 bits ind. $I^{-1}$, depending on the sampling period. The Sládeček's $Q_{B, T}$ index in this reservoir was generally 1 .

Interpretation: In addition to nutrient levels, Chla and $Q_{B T}$, the total rotifer density as a useful measure to determine the trophic status of this waterbody was explored. Our data from nutrients and total rotifer density showed that the Llano reservoir appeared to be oligotrophic.
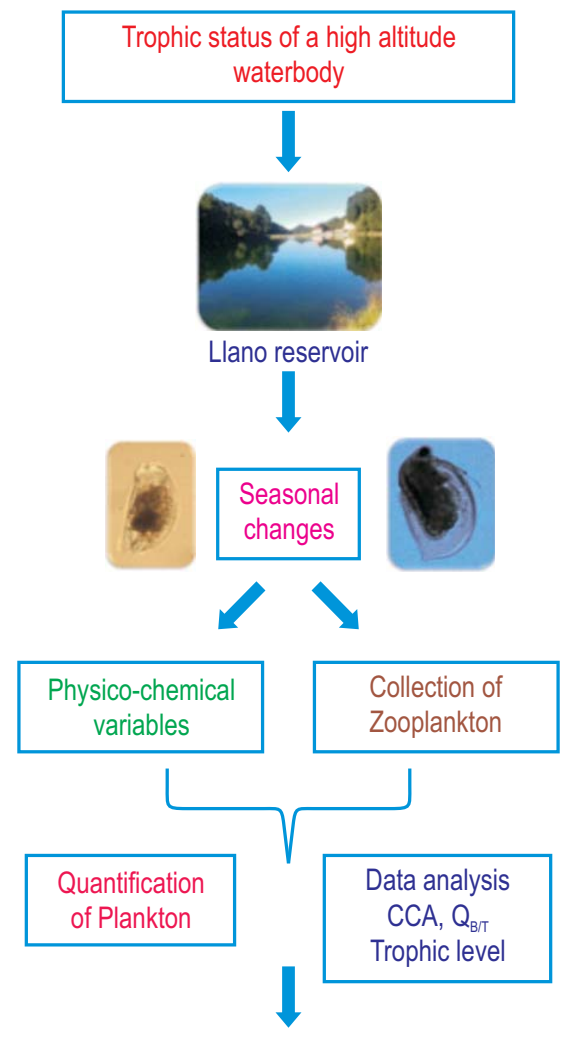

Application to Lake Management 


\section{Introduction}

Studies on rotifer density and diversity are important to acquire basic knowledge about their role in aquatic ecosystems and also for classification of the trophic status and management of waterbodies (Gulati et al., 1990; Ejsmont-Karabin, 2012). In temperate regions, studies on the long term changes (e.g., over 25 years) on rotifer diversity are available (Herzig, 1987). However, in most tropical and subtropical countries including Mexico, studies on seasonal variations of rotifers in reservoirs are few (Ramírez-García et al., 2002; Wallace et al., 2006). While the earlier limnological studies in Mexico focussed mostly on fisheries, current research considers basic and applied components (Alcocer and Sarma, 2002). In addition, during the last decade limnological studies in Mexico have been gaining momentum due to their importance in protecting and managing the limited natural resources (Alcocer and Bernal-Brooks, 2010). Mexico has about 70 large lakes and nearly 14,000 reservoirs (De la Lanza and García, 2002), but research is centered around their use for the human population as drinking water source (e.g. Valle de Bravo reservoir) or recreational purposes (e.g., Xochimilco lake) (Nandini et al., 2008; Enríquez García et al., 2009). However, for many Mexican reservoirs information on zooplankton composition, especially with regard to the rotifer fauna is unknown. Currently some of these systems are used for fisheries or as part of the tourism industry (Alcocer and BernalBrooks, 2010).

Mexican waterbodies differ greatly in altitude ( 0 to $4000 \mathrm{~m}$ above sea level), which has a consequence on limnological variables including water temperature, dissolved oxygen and the composition of phyto- and zooplankton (De la Lanza and García, 2002). Freshwater bodies located at sea level have generally typical tropical climate where the water temperature is around $28^{\circ} \mathrm{C}$ for most part of the year. On the other hand, high altitude waterbodies have a winter temperature of $10^{\circ} \mathrm{C}$ or lower (DimasFlores et al., 2008). The zooplankton communities of most freshwater bodies in Mexico are composed of mainly rotifers while the crustaceans (copepods and cladocerans) are numerically less abundant, although the latter may dominate due to their high biomass (Sarma et al., 2011; Figueroa-Sanchez et al., 2014). In certain waterbodies such as the Valle de Bravo reservoir (State of Mexico), the zooplankton are dominated by rotifers for most part of the year and cladoceran richness is reduced to a few species (Jiménez-Contreras et al., 2009). Not only due to their relatively high abundance, but also their taxonomic species richness, rotifers in Mexican waterbodies are more common than other groups (e.g., microcrustaceans) of zooplankton (De la Lanza and García, 2002). Thus a given waterbody in Central Mexico may contain as many as 30 rotifer species but with a fewer than a dozen crustacean species (Sarma and Elías-Gutiérrez, 2000; Figueroa-Sanchez et al. 2014). Though, it has been reported that tropical regions may have over
200 rotifer species (including planktonic and non-planktonic) per waterbody (Dumont and Segers, 1996), such high species richness has not been reported from Mexico to date (Sarma and Elias-Gutiérrez, 1998).

Both biotic (e.g., food availability, predation and competition) and abiotic (e.g., temperature, $\mathrm{pH}$ and salinity) factors affect the density and diversity of zooplankton (Wallace and Smith, 2013). Some species of rotifers are particularly sensitive to changes in factors like temperature, dissolved oxygen and pH (Wallace et al., 2015). In order to understand the impact of both biotic and abiotic factors on the density and diversity of rotifers, it is necessary to sample zooplankton over a long period of time (e.g., one year) (Wallace et al., 2006). However, only a few waterbodies in Mexico have been sampled regularly for zooplankton (Jiménez-Contreras et al., 2009; Nandini et al., 2016).

Llano reservoir is a high altitude waterbody and is of recreational importance in Mexico. It is also a source of revenue through fisheries, particularly that of the rainbow trout (Oncorhynchus mykiss) (Hernández Ramírez and Rosas Roa, 2010). Though the reservoir was constructed nearly 6 decades ago, quantitative information on the zooplankton abundance is not available. The aim of the present study was to present data on the seasonal variations of rotifers from the high altitude waterbody Llano dam (State of Mexico) during a one year period.

\section{Materials and Methods}

The Llano reservoir (municipality of Villa del Carbon) is located northwest of the State of Mexico (19 ${ }^{\circ} 54^{\prime} 24$ "N and $99^{\circ}$ 39' 07" W) (Fig. 1) at an altitude of $2595 \mathrm{~m}$ above sea level. The reservoir is $45 \mathrm{~m}$ deep and is surrounded by a woody and mountainous landscape. The climate is sub humid with two distinct seasons: rainy (May to September) and dry period (October to April). The average annual temperature is about $20^{\circ} \mathrm{C}$.

Rotifer sampling was done monthly from 5 different littoral zones of this reservoir for one year (August 2014 to July 2015). Sampling sites were selected based on the approximate distance from one another, accessibility and the presence of macrophytes. In addition, the depth of the sampling zones is usually $<2 \mathrm{~m}$. Eighty liters of superficial water from the reservoir were concentrated to $200 \mathrm{ml}$ through a plankton net of $50 \mu \mathrm{m}$ pore size and fixed in $4 \%$ formalin. Simultaneously, selected physicochemical parameters (dissolved oxygen (with YSI 15), temperature, pH (Potentiometer HI9812-5), conductivity (Conductronic $\mathrm{CL} 8$ ) and nutrients $\left(\mathrm{NO}_{3}^{-}\right.$and $\left.\mathrm{PO}_{4}^{-3}\right)(\mathrm{YSI} 9500$ series) were measured. In the case of chlorophyll a (Aquaflor 8000 ) we measured levels semi-quantitatively because of sampling which was close to the littoral zones causing interference from the periphytic algae associated with 


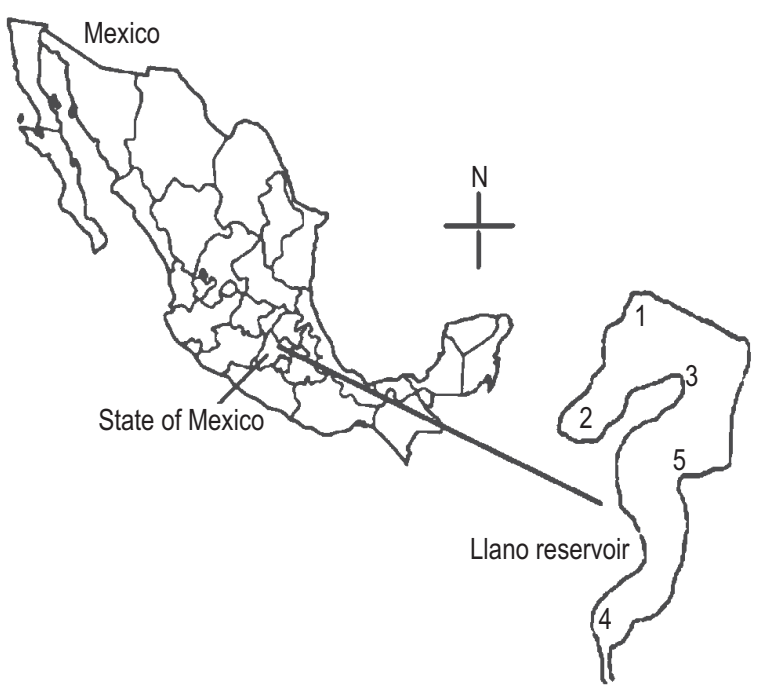

Fig. 1 : Map of Llano reservoir with sampling stations

macrophytes. While collecting rotifers from each station, we did not agitate the macrophytes which would cause inclusion of higher quantities of periphytic algae in our chla estimations.

Rotifer species were identified using specialized literature (Koste, 1978; Segers, 1995; Wallace and Snell, 2010). For the species determination of soft-bodied rotifers, we also relied on live samples and/or isolation of trophi of fixed specimens. Quantification of different rotifers species was done using a Sedgewick Rafter cell using an inverted microscope (Nikon Eclipse TS100) and 3 aliquots of $1 \mathrm{ml}$ each from the sample. Species diversity index $\left(\mathrm{H}^{\prime}\right)$ was derived using the ShannonWiener formula (Krebs, 1993):

$$
H^{\prime}=-\sum_{i=1}^{S}(P i)\left(\log _{2} P i\right)
$$

Where $H^{\prime}$ is the Shannon-Wiener Index of diversity, $P_{i}=$ proportion of $S$ made up of the $i^{\text {th }}$ species of zooplankton, total number of rotifers species.

Using ratios of the number of species of Brachionus to Trichocerca (Sládeček's $Q_{B T}$ ratio), an attempt was made to understand the trophic state of this waterbody. When the $Q_{B / T}$ ratio is $<1$, it indicates oligotrophic condition, between 1 and 2 mesotrophic and $>2$ the eutrophic level (Sládeček, 1983). Canonical Correlation Analysis (Multi-Variate Statistical Package Ver. 3.22, Kovach Computing Services, UK) was carried out to explain the variations in the rotifer abundances in relation to physico-chemical variables.

\section{Results and Discussion}

Data on the selected physico-chemical variables are presented in Figure 2. The lowest temperature was $11^{\circ} \mathrm{C}$ (zone 3) during winter, while the highest was $20^{\circ} \mathrm{C}$ during the summer. The dissolved oxygen levels varied from 3 to $11 \mathrm{mg} \mathrm{l}^{-1}$ depending on the month. The $\mathrm{pH}$ ranged from 5 to 8 , but usually was nearly neutral. The turbidity ranged from 1-3 NTU and only in a few months it was up to 10 NTU. The $\mathrm{NO}_{3}^{-}$values were $<20 \mu \mathrm{g} \mathrm{I}^{-1}$ during most part of the year except in February when it reached up to $60 \mathrm{\mu g} \mathrm{l}^{-1}$. The $\mathrm{PO}_{4}^{-3}$ was nearly $<2 \mathrm{\mu g} \mathrm{l}^{-1}$ throughout the year, with only one site during December which it was about five times higher. The pattern of environmental parameters was generally the same in all stations except for $\mathrm{NO}_{3}^{-}, \mathrm{PO}_{4}^{-3}$ and turbidity with high values in certain stations. During the study period chlorophyll a varied from 2-8 $\mathrm{g} \mathrm{I} \mathrm{l}^{-1}$; from August to December, it was higher (6$8 \mu \mathrm{gl}^{-1}$ ) than in the other months.

Zooplankton species from this reservoir were dominated by rotifers. In all 84 species of monogonont rotifers representing 18 families and 39 genera were recorded during the present study. The crustacean zooplankton species were mainly cladocerans. We were able to identify 13 species of cladocerans; two copepods were registered (Macrocyclop ssp. and Tropocyclops prasinus). Because of the difficulties in the identification of bdelloids in the preserved samples, all individuals of Bdelloidea were quantified into a single group (Table 1). Lecanidae (with 11 species), Trichocercidae (10), Brachionidae (10), Notommatidae (9) and Colurellidae (9) were dominant during the study period. Polyarthra vulgaris had the highest frequency of occurrence, being encountered in $98 \%$ of the samples, followed by Trichocerca bidens (90\%), bdelloids (81\%), Trichotria tectractis (75\%) and Keratella cochlearis (68\%). Keratella cochlearis had low density $\left(10\right.$ ind..$\left.^{-1}\right)$ nearly throughout the year, but reached to 1600 ind. ${ }^{-1}$ in the zone 4 during April. Polyarthra vulgaris had a maximum density of 355 ind. $\left.\right|^{-1}$ during February 2015, but for the rest of the year, average abundance was about 65 ind. I $^{-1}$. Trichocerca bidens, T. porcellus, bdelloids and Trichotria tetractis were the next most abundant rotifers during the study period; however, none of them exceeded 160 ind. $\mathrm{L}^{-1}$ at any sampling zone (Figure 3 ). Crustacean zooplankton generally occurred in very low density $\left(<50\right.$ ind. $\left.I^{-1}\right)$.

Data on the monthly average abundances from the five samplings zones of all rotifer species are presented in Figure 4. In April we recorded the highest density (ca. $825 \mathrm{ind} \mathrm{I}^{-1}$ ) of all rotifer species together, meanwhile for the rest of months, the density was low $<300$ ind. $l^{-1}$. Analysis on the frequency and abundance distribution of rotifers from the Llano reservoir showed that 26 species were dominants, 14 not dominant and 36 rare. Here we used the term frequency based on all samples together. The frequency was the percentage of samples that contained the species. There were no species that could be treated as common (Figure 5). Aspelta angusta, Eosphora thoa, Trichocerca insulana and Lepadella punctata are new records for Mexico. ShannonWiener index varied from 1 to 4.2 bits ind. $^{-1}$ depending on the zone and sampling period; the zones 2 and 4 presented, on an average, the higher species diversity indices ( 3.3 and 3.29 bits 
Table 1 : List of zooplankton species recorded during the study period. ${ }^{*}$ indicates new records to Mexico

\section{Rotifera}

Class: Bdelloidea

Bdelloids

Class: Monogononta

Family: Brachionidae

Anuraeopsis fissa Gosse, 1851

Brachionus calyciflorus Pallas, 1766

B. havanaensis Rousselet, 1911

B. quadridentatus Hermann, 1783

Kellicottia bostoniensis (Rousselet)

Keratella americana Carlin, 1943

K. cochlearis (Gosse, 1851)

K. tropica (Apstein, 1907)

Plationus patulus (Müller, 1786)

Platyias quadricornis (Ehrenberg, 1832)

Family: Euchlanidae

Beauchampiella eudactylota (Gosse, 1886)

Euchlanis dilatata Ehrenberg, 1832

E. incisa Carlin, 1939

Family Mytilinidae

Lophocharis oxysternon (Gosse, 1851)

L. salpina (Ehrenberg, 1834)

Mytilina bisulcata (Lucks, 1912)

M. mucronata (Müller, 1773)

M. ventralis (Ehrenberg, 1830)

Family: Trichotriidae

Macrochaetus subquadratus (Perty, 1850)

Trichotria pocillum (Müller, 1776)

T. tetractis (Ehrenberg, 1830)

Family: Lepadellidae

Colurella obtusa (Gosse, 1886)

C. uncinata (Müller, 1773)

Lepadella acuminata (Ehrenberg, 1834)

L. ovalis (Müller, 1786)

L. patella (Müller, 1773)

L. punctataWulfert, 1939*

L. rhomboides (Gosse, 1886)

L. triptera (Ehrenberg, 1832)

Squatinella mutica (Müller, 1786)

Family: Lecanidae

Lecane bulla (Gosse, 1851)

L. closterocerca (Schmarda, 1859)

L. decipiens (Murray, 1913)

L. hamata (Stokes, 1896)

L. inermis (Bryce, 1892)

L. ludwigii (Eckstein, 1883)

L. luna (Müller, 1776)

L. lunaris (Ehrenberg, 1832)

L. ohioensis (Herrick, 1885)

L. quadridentata (Ehrenberg, 1830)

Lecane sp.

Family: Proalidae

Proales decipiens (Ehrenberg, 1832)

Cladocera

Family Daphniidae

Daphnia mendotae (Birge, 1918)

Ceriodaphnia dubia Richard, 1804
Family: Notommatidae

Cephalodella catellina (Müller, 1786)

C. forficula (Ehrenberg, 1830)

C. gibba (Ehrenberg, 1830)

C. stenroosi Wulfert, 1937

Eosphora thoa Harring\& Myers, 1924*

Monommata arndti Myers, 1930

Notommata copeus Ehrenberg, 1834

N. glyphura Wulfert, 1935

N. tripus Ehrenberg, 1838

Pleurotrocha petromyzon (Ehrenberg, 1830)

Family Scaridiidae

Scaridium longicaudum (Müller, 1786)

Family: Trichocercidae

Trichocerca bidens (Lucks, 1912)

T. capucina (Wierzejski \& Zacharias, 1893)

T. cylindrica (Imhof, 1891)

T. elongata (Gosse, 1886)

T. insulana (Hauer, 1937)*

T. porcellus (Gosse, 1851)

T. pusilla (Jennings, 1903)

T. similis (Wierzejski, 1893)

T.tenuior (Gosse, 1886)

T. weberi(Jennings, 1903)

Family: Gastropodidae

Ascomorpha ecaudis Perty, 1850

A. ovalis (Bergendal, 1892)

Gastropush yptopus (Ehrenberg, 1838)

Family: Synchaetidae

Polyarthra dolichoptera Idelson, 1925

P. vulgaris Carlin, 1943

Synchaeta oblonga Ehrenberg, 1832

Family:Asplanchnidae

Asplanchna girodide Guerne, 1888

A. priodonta Gosse, 1850

Family: Dicranophoridae

Aspelta angusta Harring \& Myers, 1928 *

Dicranophoroides caudatus (Ehrenberg, 1834)

Dicranophorus grandis (Ehrenberg, 1832)

Family: Testudinellidae

Pompholyx sulcata Hudson, 1885

Testudinella patina (Hermann, 1783)

Family: Flosculariidae

Floscularia sp.

Ptygura brachiata (Hudson, 1886)

P. crystallina (Ehrenberg, 1834)

Limnias melicerta Weisse, 1848

Family: Filiniidae

Filinialongiseta (Ehrenberg, 1834)

F. pejleriHutchinson, 1964

Family Collothecidae

Collotheca campanulata (Dobie, 1849)

Collothecasp.

P. quasidenticulatus Smirnov, 1996

P. trigonellus (Müller, 1776)

Chydorus brevilabris Frey, 1980 
Simocephalus latirostris Stingelin, 1906

Scapholeberis armatafreyi Dumont \& Pensaert, 1983

Family Bosminidae

Bosmina longirostris (Müller, 1785)

Family Chydoridae

Pleuroxus denticulatus Birge, 1879

P. varidentatus Frey, 1993
Alona guttata Sars, 1872

Camptocercus dadayi Stingelin, 1913

Leydigia cf. louisi mexicana Kotov, Elías-Gúttierrez \& Nieto, 2005

Copepoda

Macrocyclopssp.

Tropocyclops prasinus (Fischer, 1860) ind. $^{-1}$, respectively) while the remaining three zones had lower species diversity index values $\left(2.0-2.6\right.$ bits ind.$\left.^{-1}\right)$ during the sampling period (Fig. 6). The mean annual Sládeček's $Q_{B / T}$ index in this reservoir was 1 . When derived on monthly basis, the index exceeded 1.3 in January 2015.

In the (CCA) the first two ordination axes explained the $57 \%$ of variance of the rotifer density (Fig. 7). Several species of the genus Trichocerca were positively correlated with turbidity, while species of the family Colurellidae were corrected with chl. a. The most dominant species, Polyarthra vulgaris, was correlated with nutrients, which were nearly stable during the sample period. Temperature had influence on Keratella cochlearis. CCA showed three main groups, one formed by species associated with turbidity and chl. $a$, another with nutriments and the third one by $\mathrm{pH}, \mathrm{DO}$ and temperature. Ascomorpha ovalis did not have any significant correlation with any of the measured variables, while bdelloid group was affected by the combination of the measured environmental variables.

The high altitude waterbodies in Mexico have some similarity for some physico-chemical variables. For example, the Iturbide waterbody (3,310 msl) (State of Mexico, Mexico) has water temperature in the range of $9-20^{\circ} \mathrm{C}$ and DO levels at 11-18 $\mathrm{mg} \mathrm{L}^{-1}$ (Sarma et al., 2011) and the Valle de Bravo reservoir, also from the State of Mexico, (1830 msl) with $18-24^{\circ} \mathrm{C}$ and DO 2-8 $\mathrm{mg}$ $\mathrm{L}^{-1}$ (Nandini et al., 2008). Most high altitude waterbodies in Mexico are alkaline (e.g., Xochimilco, Nandini et al., 2015) or nearly neutral (Sarma and Elías-Gutiérrez, 2000) but few are slightly acidic (e.g., Nevada de Toluca: Sarma et al., 1996). In general Mexican freshwater bodies are not very deep $(<20 \mathrm{~m})$ and some of them very shallow (0.5-3 m) such as Lake Xochimilco and Lake Chapala (De la Lanza and García, 2002). In shallow lakes, transparency is low (about $10 \mathrm{~cm}$ ) due to high turbidity from particulate inorganic matter and cyanobacterial blooms (Nandini et al., 2005). For example, in the high altitude waterbody, Chimaliapan, the turbidity was as high as 11 NTU (GarcíaGarcíaet al., 2012). In drinking water reservoirs, the recommended turbidity is about 5 NTU (WHO, 2006), but most often this exceeds in Mexican reservoirs (Ramírez-García et al., 2002; Alcocer and Bernal-Brooks, 2010).

The levels of nitrates observed here are lower than those recorded in other high altitude waterbodies such as Lake Xochimilco (Enriquez-García et al., 2009). The elevated levels of nutrients during the winter months in this study could be associated with agricultural activities from nearby fields, where addition of fertilizers was common during this period. The nutrient levels clearly indicated that this waterbody was oligotrophic during most part of the sampling period; the chlorophyll a levels were nearly $5 \mu \mathrm{gl}^{-1}$. This supports the view that this waterbody is possibly oligotrophic (Krebs, 1993).

We did not specifically aim at collecting benthic or periphytic rotifers. Since the list of rotifer species suggests that more than $80 \%$ of them are typically planktonic, semi-planktonic or even tychoplanktonic and these were obtained in plankton net without agitating the macrophytes, we treated them as zooplankton, although this refers to mostly rotifers. The number of observed rotifer families was higher than that reported in some other reservoirs of this region (e.g., Valle de Bravo reservoir: Ramírez-García et al., 2002; Nandini et al., 2008; JiménezContreras et al., 2009), but similar to a few others (e.g., the Iturbide reservoir: Sarma et al., 2004). The number of rotifer species recorded from the present waterbody was much higher than many other waterbodies in this region. For example, studies from the Valle de Bravo reservoir carried out for more than 15 years revealed the presence of not more than 35 species (Ramírez-Garcíaet al., 2002; Nandini et al., 2008). However, a few other high altitude lakes of this region have comparable species richness. For example, about 50 rotifer species are known from the lake Xochimilco based on one time collection (Flores Burgos et al., 2003) or higher (> 60 species) through seasonal studies as recorded in other high altitude waterbodies (García-García et al., 2012). All these high altitude waterbodies are located within the Central part of the Mexican Republic. In tropical low level waterbodies of Mexico (e.g., reservoir Valerio Trujano) physical and chemical variables, other factors, notably predation by invertebrates, strongly influence the species diversity and community structure of rotifers (Vázquez-Sánchez et al., 2014). For example, predatory copepods are known to have a strong effect on planktonic rotifers as evident from field observations (Devetter, 1998) or laboratory experiments (Sarma et al., 2013). In this work, though we did not estimate the density of copepods, we observed that their abundance was low (1-5 ind. $\left.I^{-1}\right)$. In deep reservoirs, which is the case here, unlike crustacean zooplankton, planktonic rotifers suffer from fish predation for a few weeks, especially during the larval stages (Jørgensen et al., 2005). Therefore, fish predation indirectly benefits rotifers by eliminating the crustacean competitors. This may have been the situation in this reservoir because fish such as rainbow trout are present which feed on crustaceans. However, we have no quantitative information on fish feeding in this waterbody. Competition with 

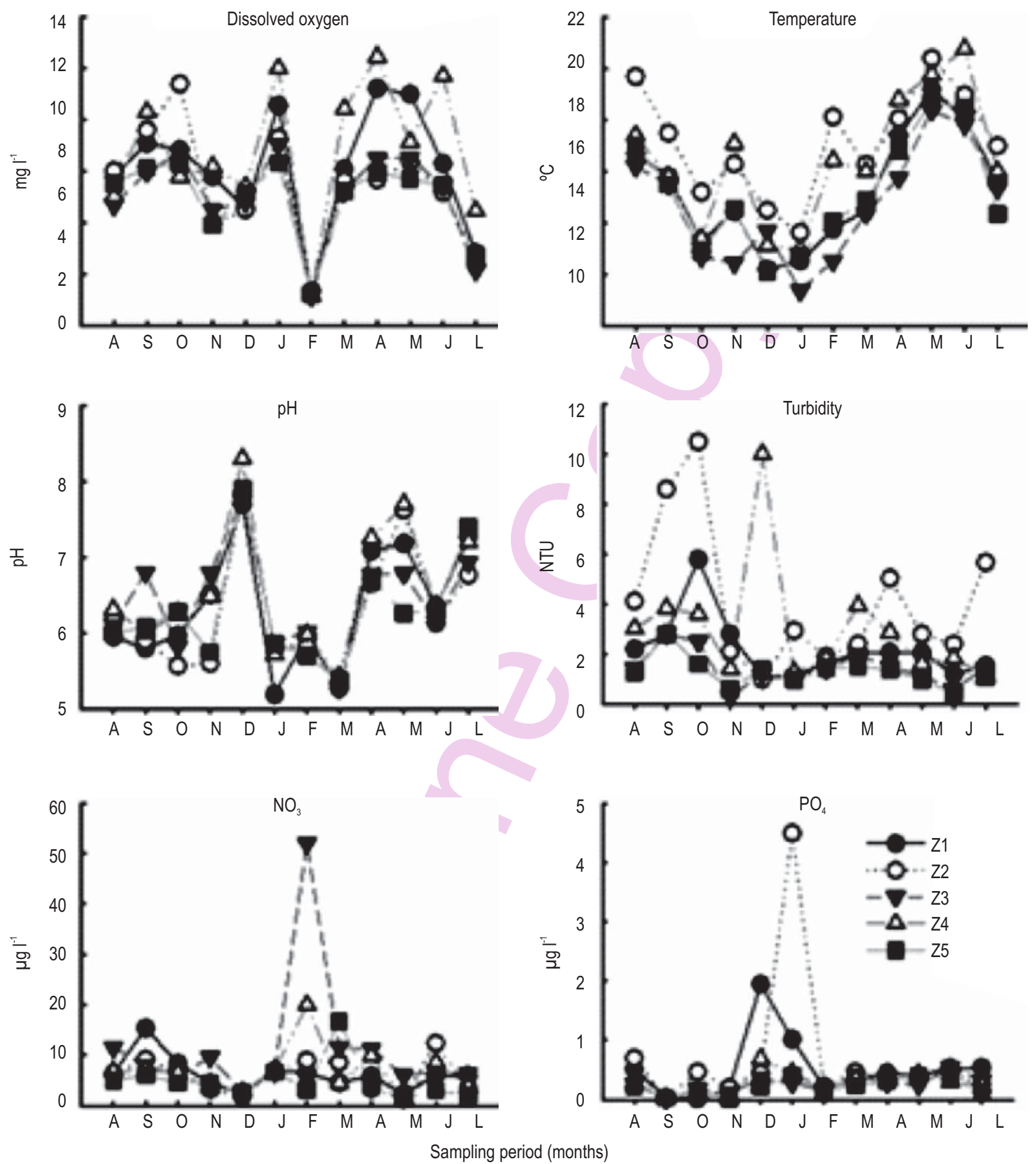

Fig. 2 : Monthly variations in the selected physico-chemical variables from the Llano reservoir during 2015-2015 from five different stations

cladocerans can result in reduced rotifer abundances (Gilbert, 1985), which can affect the index of trophic state based on total rotifer densities. However, in our work, the densities of large cladocerans are extremely low $\left(<5\right.$ ind..$\left.^{-1}\right)$ and thus negative effect of competition from Cladocera, if any, may be expected to be low.
In waterbodies dominated by $K$. cochlearis and $P$. vulgaris, the density of brachionid rotifers is low (Devetter, 1998). This is also the case in this waterbody where, though there were three species of Brachionus, each of them generally occurred in low density $\left(<50\right.$ ind. $\left.I^{-1}\right)$. Normally, in tropical waters Brachionus 

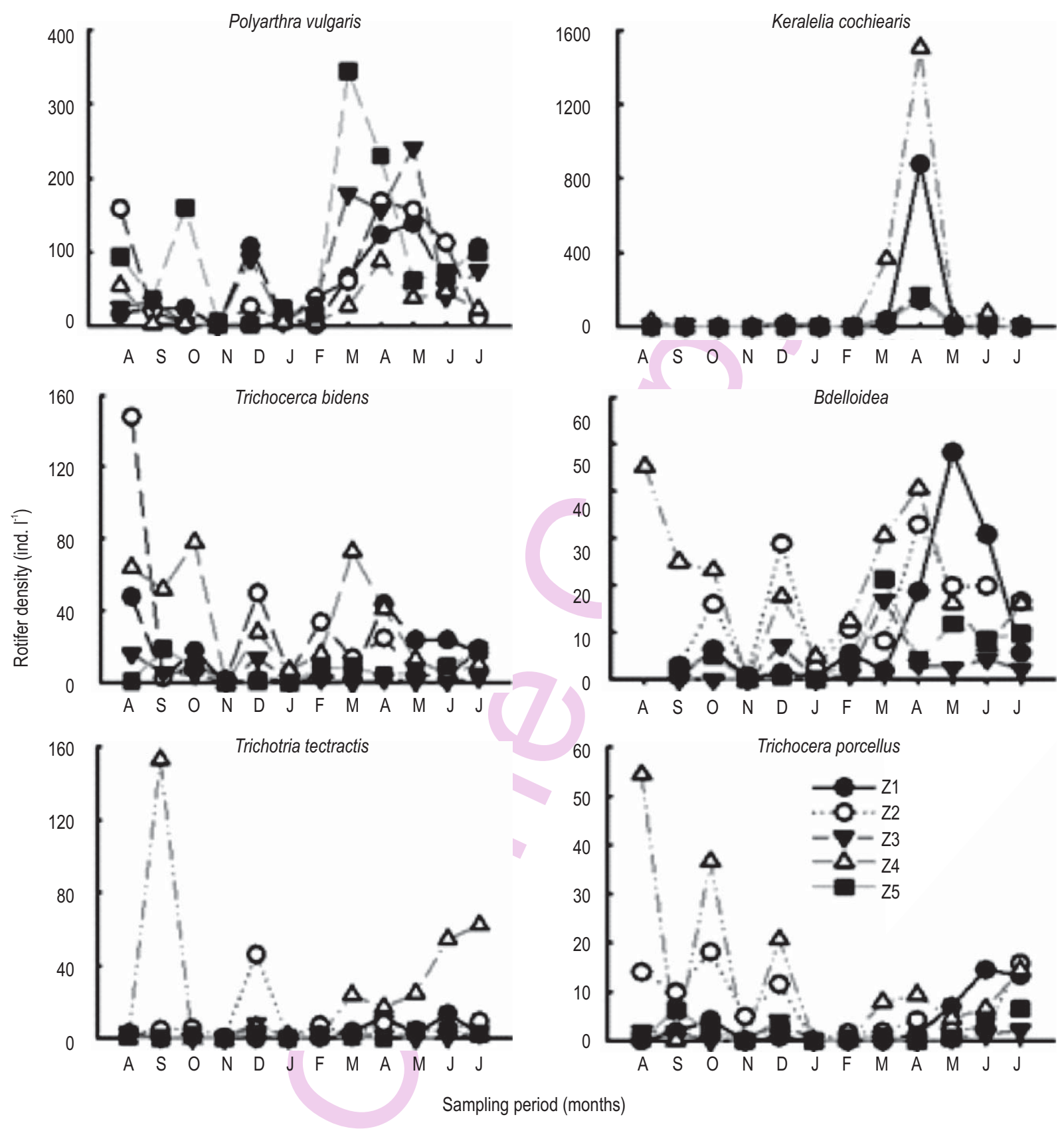

Fig. 3 : Monthly variations in the abundance (ind..$^{-1}$ ) dominant rotifer species from the Llano reservoir during 2015-2015 from five different stations; density data of bdelloids were combined. Note the differences on the scale of the $y$-axis

species dominate (Athibai et al., 2013). However, in high altitude tropical waters, this genus is less dominant, possibly due to low water temperature present during most part of the year. The mean Shannon Wiener species diversity index was about 2.5 bit ind $\mathrm{I}^{-1}$. This suggests that this reservoir is less contaminated (Wetzel, 2001) compared to other similar waterbodies in this region such as lake Xochimilco, which receive partially treated wastewater for refilling (Enrique.z-García et al., 2009).

Though the nutrient levels were generally stable during the sampling period, some rotifer species were positively correlated to the nutrient gradient. For example, Trichocerca ssp. 


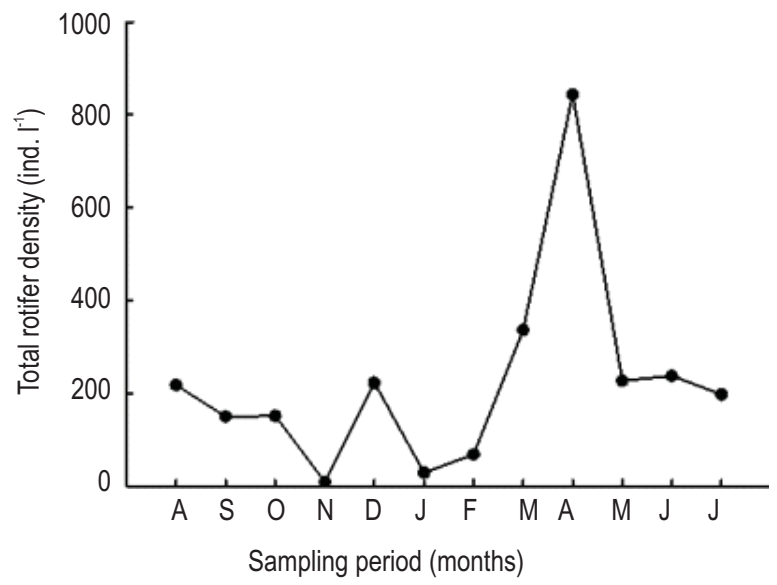

Fig. 4 : Monthly variations in the total abundance (ind. $I^{-1}$ ) of all rotifer species from the Llano reservoir during 2015-2015

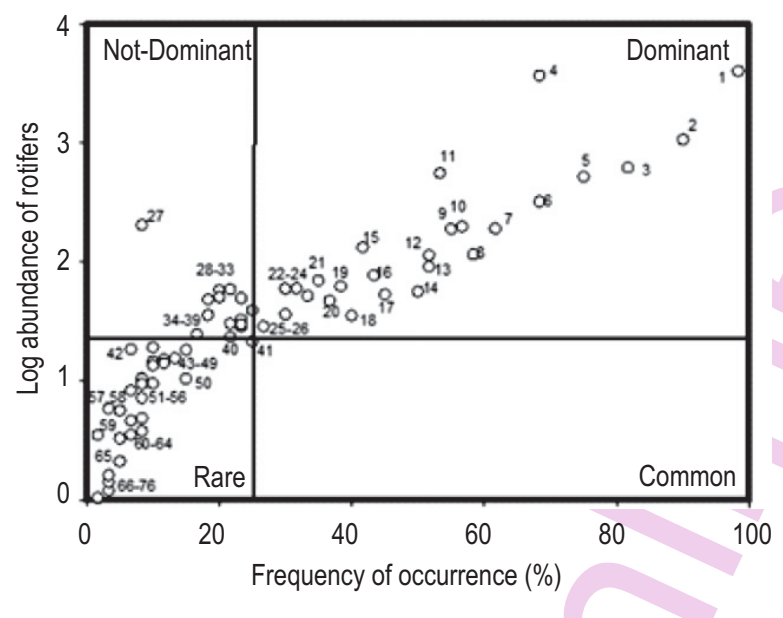

Fig. 5 : Frequency and abundance distribution of rotifer species from the Llano reservoir. Dominant: 1.-P. vulgaris 2.-T. bidens 3.-Bdelloidea 4.-K. cochlearis 5.-T. tectractis 6.-T. porcellus 7.-A. ovalis 8.-P. dolichoptera 9.L. ovalis 10.-L. patella 11.-T. similis 12.-L. lunaris 13.-T. cylindrica 14.-S. oblonga 15.-C. uncinata 16.-A. fissa 17.-T. patina 18.-C. gibba 19.-S. lamellaris 20.-M. actices 21.-C. obtusa 22.-A. priodonta 23.-L. closterocerca 24.-T. tenuior 25.-M. ventralis 26.-T. capucina Temporal: 27.-L. sp. 28.-T. weberi 29.-T. insulana 30.-T. pocillum 31.-E. incisa 32.-K. bostoniensis 33.-L. acuminata 34.-P. patulus 35.-L. bulla 36.-D. grandis 37.-A. ecaudis 38.-T. elongata 39.-C. catellina 40.-M. mucronata. Rare: 41.-L. triptera 42.-C. forficula 43.-A. angusta 44.-K. americana 45.-L. rhomboides 46.-G. hyptopus 47.-L. ohioensis 48.-L. oxysternon 49.-A. girodi 50.-P. quadricornis 51.-T. pusilla 52.-E. dilatata 53.-D. caudatus 54.-L. Iuna 55.-S. Iongicaudum 56.-M. bisulcata 57.-L. punctata 58.-B. quadridentatus 59.-E. thoa 60.-L. ludwigi 61.-B. calcyflorus 62.-C. sp 63.-C. steenrosi64.-M. subquadratus 65.-L. salpina 66.- P. sulcata 67.-F. pejleri68.-B. eudactylota69.-N. copeus 70.-L. inermis 71.-L. hamata 72.B. havanaensis 73.-K. tropica 74.-L. quadridentata 75.-N. tripus 76.- F. longiseta and Colurellidae were positively linked to turbidity and chl. a, while $K$. cochlearis were positively linked to $\mathrm{pH}, \mathrm{DO}$ and temperature. Raptorial species such as Polyarthra were related to $\mathrm{NO}_{3}{ }^{-1}$. Obertegger and Manca (2011) have reported the response of rotifer functional groups to changing trophic state of Lago Maggiore based on long term data. They observed that the raptorial taxa such as Asplanchna priodonta, Synchaeta pectinata and Synchaetatremula, dominated the lake during oligo and meso-oligotrphic state. Obertegger et al. (2011) have also derived the ratio of raptorial to microphagous species and applied this to explain rotifer dynamics. According to them, the different genera of rotifers including Ascomorpha, Asplanchna, Collotheca, Gastropus, Ploesoma, Polyarthra, Synchaeta and Trichocerca are raptorials while others such as Brachionus, Conochilus, Euchlanis, Filinia, Floscularia, Kellicottia, Keratella, Lecane, Notholca, Testudinella and Trichotria and microphagous. Since bdelloids mostly feed on bacteria (Koste, 1978), they may be treated as microphagous too. In our work, in terms of species numbers, the microphagous taxa were nearly the same as raptorials. Therefore, the ratios of these two functional groups in explaining their seasonal variations can be more complex (Obertegger et al., 2011). In addition, in present waterbody, bdelloids showed no significant relation with any of the chosen physico-chemical variables. This is hardly surprising since bdelloids are generally less sensitive than monogononts to changes in the environment (Snell and Joaquim-Justo, 2007). It was also possible since we could not separately identify them to even genera level, the relative sensitivities of different taxa of bdelloids were masked due to clubbing them into a single group.

Rotifers can be a proxy for the trophic status of a given waterbody (Sládeček, 1983). However, due to the difficulty in identification, the use of rotifers as bioindicators in tropical and subtropical regions of the world is still limited (Snell and JoaquimJusto, 2007). The distribution of Anuraeopsis fissa, Brachionus calyciflorus, Pompholyx sulcata, and Trichocerca pusilla in oligotrophic waterbodies, as also observed here, is rare but not entirely surprising. For example, previous studies show the occurrence of Brachionus calyciflorus and Anuraeopsis fissa in oligotrophic lakes (e.g., Bonita Pond, Brazil) (Starling, 2000), which are generally considered typical to meso- or eutrophic waterbodies (Ejsmont-Karabin, 2012). This suggests that certain rotifer species which tolerate meso- or eutrophic conditions are also capable of reproducing and maintaining a population under oligo-trophic conditions. This may have relation to the threshold food requirements of individual species (Stemberger and Gilbert, 1985). For example, the typical eutrophic Anuraeopsis is expected to survive and reproduce in oligotrophic lakes due to its low threshold food requirements and competitive ability to outcompete larger species which require higher quantity of diet for survival and reproduction (Sarma et al., 1996).

The much used Sládeček's $Q_{B / T}$ ratio of Brachionus to Trichocerca is not always useful in tropical reservoirs (Nandini et 


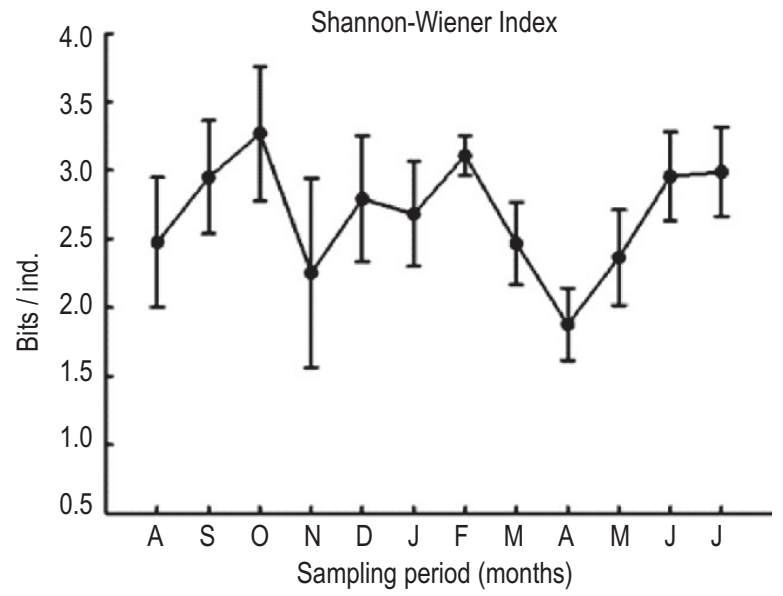

Fig. 6 : Monthly variations in the Shannon-Wiener index from the Llano reservoir during 2014-2015. Values present mean \pm standard error based on 5 sampling points

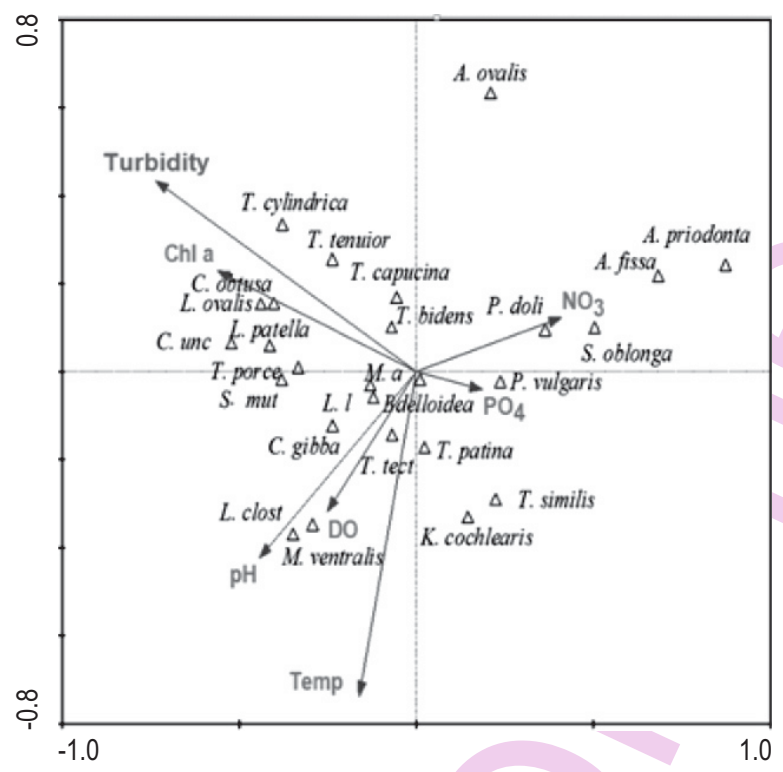

Fig. 7 : Canonical correlation analysis of dominant rotifer species. Sq. mut; Squatinella mutica T. tect; Trichotriate ctractis, P. doli; Polyarthra dolichoptera, M. a; Monommata actices, L. I; Lecane lunaris, T. porce: Trichocerca porcellus, C. unc; Colurellauncinata

al., 2008). Here we found the mean annual $Q_{B T}$ ratio was 1 but exceeded this value to 1.3 only in January. The higher $Q_{B / T}$ ratio in January is possibly due to low species diversity of Trichocerca which may be due their sensitivity to high nutrient levels and low $\mathrm{pH}$ recorded in this waterbody. The $\mathrm{Q}_{\mathrm{B} T}$ ratio of 1 during most part of the year suggests that the reservoir has a tendency of slightly mesotrophic. However, the levels of phosphates and nitrates indicate the reservoir is oligotrophic based on the threshold values given in Wetzel (2001). We would like to emphasize that what we presented here was orthophosphate $\left(\mathrm{PO}_{4}^{-3}\right)$ concentrations, which are low or limiting at high growth rates of phytoplankton, but when organically bound phosphates present, then the total phosphorus levels can be high (Jansson, 1993). We did not measure here the total phosphorus which is a significant parameter for deriving trophic indicators such as Carlson index (Carlson, 1977).

In addition to the ratio of individual species of rotifers such as $Q_{B T}$, their total density is also considered as a useful measure to determine the trophic status of a given waterbody. Increase in nutrient load enhances the phytoplankton density which in turn favors high growth of zooplankton, especially the rotifers (Wallace et al., 2015). Thus, if the total density of rotifers from a given waterbody is $<500$ ind. $I^{-1}$, then it reflects an oligotrophic condition, while 500 -1000 mesotrophic, 1000-2500 eutrophic and 30004000 ind. $L^{-1}$ hypertrophic situations (Ejsmont-Karabin, 1995; May and O'Hare, 2005; Ejsmont-Karabin, 2012). In this work the mean total density of rotifers from all measured sites was $<300$ ind. $L^{-1}$. This also suggests that the waterbody has oligotrophic conditions.

In conclusion our data showed that the Llano reservoir appears to be oligotrophic based on nutrient levels, chlorophyll a and total rotifer densities, although the ratio of Brachionus to Trichocerca $\left(Q_{B \pi}\right)$ indicates the waterbody is slightly mesotrophic. Further studies including estimation of total phosphorus are still needed to understand the trophic state of this waterbody.

\section{Acknowledgments}

Late Brian Moss (UK) made several constructive comments on our manuscript. N. Korovchinsky (Russia) confirmed the identification of cladoceran species. MEMC thanks PCMyL (UNAM) and CONACyT (Mexico) for support. SSSS and SN thank FES Iztacala (Division of Investigation and Postgraduate Studies). Funding from PAPIIT- IA203315 (UNAM) is gratefully acknowledged.

\section{References}

Alcocer, J. and F.W. Bernal-Brooks:Limnology in Mexico. Hydrobiologia, $644,15-68$ (2010).

Alcocer, J. and S.S.S. Sarma: Preface. Hydrobiologia, 467, page vii (2002).

Athibai, S., H. Segers and L.O. Sanoamuang: Diversity and distribution of Brachionidae (Rotifera) in Thailand, with a key to the species. J. Limnol., 72, 345-360(2013).

Carlson, R.E.: A trophic state index for lakes. Limnology and Oceanography, 22, 361-369 (1977).

De La Lanza, E.G. and C.J.L. García: Lagos y presas de México. AGT Editor S.A., Mexico City, Mexico (2002).

Devetter, M.: Influence of environmental factors on the rotifer assemblage in an artificial lake. Hydrobiologia, 387/388, 171-178 (1998).

Dimas-Flores, N., J. Alcocer and J. Ciros-Peréz: The structure of the 
zooplankton assemblages from two neighboring tropical high mountain lakes. J. Freshwater Ecol., 23, 21-31 (2008).

Dumont, H.J. and S.V. Negrea: Introduction to the Class Branchiopoda. Backhuys Publishers, Leiden(2002).

Dumont H.J. and H. Segers: Estimating lacustrine zooplankton species richness and complementarity. Hydrobiologia, 341, 125-132 (1996).

Ejsmont-Karabin, J.: Rotifer occurrence in relation to age, depth and trophic state of quarry lakes. Hydrobiologia, 313/314, 21-28 (1995).

Ejsmont-Karabin, J.: The usefulness of zooplankton as lake ecosystem indicators: Rotifer trophic state index. Pol. J. Ecol., 60, 339-350 (2012).

Enríquez-García, C., S. Nandini and S.S.S. Sarma: Seasonal dynamics of zooplankton in Lake Huetzalin, Xochimilco (Mexico City, Mexico). Limnologica, 39, 283-291 (2009).

Figueroa-Sánchez, M.A., S. Nandini and S.S.S. Sarma: Zooplankton community structure in the presence of low levels of cyanotoxins: A case study in a high altitude tropical reservoir (Valle de Bravo, Mexico). J. Limnology, 73, 157-166 (2014).

Flores-Burgos, F., S.S.S. Sarma and S. Nandini: Estudio preliminar sobre la fauna de rotíferos de Xochimilco (México). El agua de cuenca de México. Sus problemas históricos y perspectivas de solución. Proceedings of the Second International Conference on Xochimilco, Ecological Park of Xochimilco, UAM Xochimilco, Mexico City, Mexico,1, 163-171(2003).

García-García, G., S. Nandini, S.S.S. Sarma, J. Martínez-Jerónimo and J. Jiménez-Contreras: Impact of chromium and aluminium pollution on the diversity of zooplankton: A case study in the Chimaliapan wetland (RAMSAR Site) (Lerma basin, Mexico). J. Environ Sci. Hlth. A, 47, 534-547 (2012).

Gilbert, J.J.: Suppression of rotifer populations by Daphnia: A review of the evidence, the mechanisms, and the effects on zooplankton community structure. Limnology and Oceanography, 33, 12861303 (1985).

Gulati, R.D., E.H.R.R. Lammens, M.L. Meijer and E. Van Donk, (eds), Biomaniputation - Tool for Water Management. Hydrobiologia, 200/201, 1-627 (1990).

Hernández Ramírez, N. and J. Rosas Roa: Ecoturismo e infraestructura vial como detonante de la economía local: caso de estudio: Villa del Cárbon, 2009. Quivera, 12, 37-57 (2010).

Herzig, A., The analysis of planktonic rotifer populations: A plea for long-term investigations. Hydrobiologia, 147, 163-180 (1987).

Jansson, M.: Uptake, exchange, and excretion of orthophosphate in phosphate-starved Scenedesmus quadricauda and Pseudomonas K7. Limnology and Oceanography, 38, 1162-1178 (1993).

Jiménez-Contreras, J., S.S.S. Sarma, M. Merino-lbarra and S. Nandini: Seasonal changes in the rotifer (Rotifera) diversity from a tropical high altitude reservoir (Valle de Bravo, Mexico). J. Environ. Biol., 30, 191-195 (2009).

Jørgensen, S.E., H. Löffler, W. Rast and M. Straškraba: Lake and Reservoir Management. Developments in Water Science, 54, Elsevier,Amsterdam (2005).

Koste, W.: Rotatoria. 2 vols. Borntraeger, Berlin (1978).

Krebs J.R.: Ecological Methodology. Harper Collins Publ., New York (1993).

May, L. and M. O'hare: Changes in rotifer species composition and abundance along a trophic gradient in Loch Lomond, Scotland, UK. Hydrobiologia, 546, 397-404 (2005).
Nandini, S., P. Ramírez-García and S.S.S. Sarma: Seasonal variations in the species diversity of planktonic rotifers in Lake Xochimilco, Mexico. J. Freshwater Ecol., 20, 287-294 (2005).

Nandini, S., M. Merino-Ibarra and S.S.S. Sarma: Seasonal changes in the zooplankton abundances of the reservoir Valle de Bravo (State of Mexico, Mexico). Lake Reser. Manag., 24, 321-330 (2008).

Nandini, S., P. Ramírez-García and S.S.S. Sarma: Water quality indicators in Lake Xochimilco, Mexico: Zooplankton and Vibrio cholera. J. Limnol., 75, 91-100 (2016).

Obertegger, U. and M. Manca: Response of rotifer functional groups to changing trophic state and crustacean community. J. Limnol., 70, 231-238 (2011)

Obertegger, U., H.A. Smith, G. Flaim and R.L. Wallace: Using the guild ratio to characterize pelagic rotifer communities. Hydrobiologia, 662, 157-162 (2011).

Ramírez-García, P., S. Nandini, S.S.S. Sarma, E. Robles-Valderrama, I. Cuesta and D. Hurtado-Maria: Seasonal variations of zooplankton abundance in the freshwater reservoir Valle de Bravo (Mexico). Hydrobiologia, 467, 99-108 (2002).

Sarma, S.S.S. and M. Elías-Gutiérrez: Rotifer diversity in a central Mexican pond. Hydrobiologia, 387/388, 47-54 (1998).

Sarma, S.S.S. and M. Elías-Gutiérrez: Rotifers from Mexico: New records in high altitude ponds. The Southwestern Naturalist, $\mathbf{4 5}$ 366-373 (2000).

Sarma, S.S.S., N. lyer and H.J. Dumont: Competitive interactions between herbivorous rotifers: importance of food concentration and initial population density. Hydrobiologia, 331, 1-7 (1996).

Sarma, S.S.S., J. Jiménez-Contreras, R. Fernández, S. Nandini and G. García-García: Functional responses and feeding rates of Mesocyclops pehpeiensis Hu (Copepoda) fed different diets (rotifers, cladocerans, alga and cyanobacteria). J. Natur. Hist., 47, 841-852 (2013).

Sarma, S.S.S., M. Elías-Gutiérrez and S.S. Carmen: Rotifers from high altitude crater lakes at Nevado de Toluca, State of Mexico (Mexico). Hidrobiologica, 6, 33-38 (1996).

Sarma, S.S.S., L.R. Osnaya-Espinosa and C.R. Aguilar-Acosta: Seasonal variations in zooplankton abundances in the Iturbide reservoir (Isidro Fabela, State of Mexico, Mexico). J. Environ. Biol., 32, 473-480 (2011).

Segers, H.: The Lecanidae (Monogononta). In: Guides to the Identification of the Microinvertebrates of the Continental Waters of the World (Ed.: H.J. Dumont). Vol. 2, SPB Publishers, Leiden(1995).

Sládeček, V.: Rotifers as indicators of water quality. Hydrobiologia, 100, 169-201(1983).

Snell, T.W. and C. Joaquim-Justo: Workshop on rotifers in ecotoxicology. Hydrobiologia, 593, 227-232(2007).

Starling, F.L.D.R.M.: Comparative study of the zooplankton composition of six lacustrine ecosystems in Central Brazil during the dry season. Revista Brasileira de Biologia, 60, 101-111(2000).

Stemberger, R.S. and J.J. Gilbert: Body size, food concentration, and population growth in planktonic rotifers. Ecology, 66, 1151-1159 (1985)

Vázquez-Sánchez, A., S. Nandini and S.S.S. Sarma: Diversity and abundance of rotifers during an annual cycle in the reservoir Valerio Trujano (Tepecoacuilco, Guerrero, Mexico). Inland Waters, 4, 293-302 (2014).

Wallace, R.L. and A.H. Smith: Rotifera. eLS. John Wiley \& Sons: Chichester (2013). 
Wallace, R.L., T.W. Snell and H.A. Smith: Rotifer: Ecology and General Biology. In: Thorp and Covich's Freshwater Invertebrates (Eds.: J.H. Thorp and D.C. Rogers). Elsevier, Waltham, MA. pp. 225-271 (2015).

Wallace, R.L., T.W. Snell, C. Ricci and T. Nogrady: Rotifera biology, ecology and systematics. 2 ed. Kenobi Productions Ghent (2006).

Wallace, R.L. and T.W. Snell: Rotifera. Chapter 8. In: Ecology and Classifications of North American Freshwater Invertebrates (Eds.:
J. Thorp and A. Covich), 3rd Edn., Elsevier. Oxford, pp. 173-235 (2010).

Wetzel, R.G.: Land-water interface: Attached Microorganisms, Littoral Algae and Zooplankton. In: Limnology: Lake and River Ecosystem. Part 19: Academic Press, San Diego (2001).

WHO: World Health Organization. Guidelines for drinking-water quality. Incorporating first addendum. Vol. 1, Recommendations. $-3^{\text {rd }}$ Edn., Geneva (2006). 